\title{
Why Not Eminently Maritime UN Peacekeeping Operations?
}

\section{André Panno Beirão*}

\begin{abstract}
Although the UN Charter does not explicitly provide for Peacekeeping Operations (PKOs), they have become one of the UN's most important means of preserving peace and international security. Some of the greatest threats to international peace and security do not occur on 'UN Member States territory', but at sea. The internationally significant and long-standing phenomenon of maritime piracy initially led to international action off the coast of Somalia, but other regions affected by criminal acts at sea (including the Straits of Malacca, the Gulf of Guinea and the Mediterranean Sea) are reinforcing the need for international action. In most of these situations, the UN has not acted directly, but called on multilateral or regional bodies to do so. Earlier experiences in PKOs at sea, in Cambodia, East Timor, Haiti, and most recently in Lebanon, undertaken by the UN Interim Force in Lebanon (UNIFIL), begin to provide a basis for building a naval PKO doctrine. This article argues that it is legitimate for the UN to undertake direct action when facing threats to maritime security, making use of an empirical example and suggests that new instances of criminal acts at sea, such as those in the Gulf of Guinea, may best be dealt with under a direct UN mandate.
\end{abstract}

Keywords: Maritime Peace Operations; Maritime Security; Law of the Sea; Piracy; Defence Arrangements.

\section{Introduction}

It is often said that new problems enable new solutions, but this adage can sometimes be misleading. History can (and should) be used as a means of analysing new problems, and a basis for solving them. From another perspective, solutions already adopted for solving very different problems may be used - possibly with adjustments - to address new ones. The two perspectives of 'old problems / new solutions' and 'old solutions / new problems' lead to different methodological approaches. The first proceeds inductively, while the second proceeds deductively.

The problem of combating the causes of insecurity at sea is neither recent nor new, but the search for solutions is still continuing, and may suggest new approaches. On the other hand, strategies for ensuring security that have already worked fairly well in other settings - especially land-based conflicts - could be adapted for innovative solutions.

*Naval War College, Rio de Janeiro-RJ; Brazil; beirao.ap@gmail.com. 
In line with this, the purpose of this article is to examine the feasibility of using maritime Peacekeeping Operations (PKOs) - led by the UN - and prioritising the use of naval forces as a means of maintaining maritime security. The first issue that arises is to define the subject of this analysis, namely maritime security. Like the vastness of the sea, the concept of maritime security encompasses many underlying issues that extends far beyond the scope of this study. Second, this study intends to employ a deductive approach to outlining how the UN has developed the use of PKOs to achieve its goal of maintaining peace and security. In what follows, I will present some initiatives already undertaken in the maritime context, along with possible approaches that could be advanced by means of inductive arguments.

I intend to make inductive arguments to the effect that solutions to previous security problems in different settings may be used to converge on solutions to new ones. This will only be possible if the proposed solutions are tried and tested, and conceptual or regulatory gaps in the new context filled. I therefore intend to point to new possibilities, while acknowledging the uncertainties surrounding the adoption of new and innovative solutions.

\section{Defining maritime security}

The first point to be noted is the difficulty of defining the subject - safety and security at sea - in light of the linguistic and consequently conceptual differences between these two terms. This may seem trivial, but it isn't. In both English and French, there are two different words for conveying two different concepts: security and safety in English, and securité and sûreté in French. Spanish and Portuguese only have a single word for both concepts: segurança in Portuguese, and seguridad in Spanish. Obviously, segurança in the sense of safety is distinct from segurança in the sense of security: the former emphasises the aspect of ensuring that ships can navigate without risks to their physical integrity, while the latter emphasises the aspect of preventing the threats and violent actions that may occur at sea (Beirão 2014). Portuguese speakers frequently use the word salvaguarda for safety, and segurança for security. While this lack of semantic nuance in Portuguese is discussed in various articles, theses and other documents, it is important to note that its lexicon does allow for differentiation. I will focus primarily on the security aspect, but pay some attention to the safety aspect as well.

The next task is to define maritime security, and the causes of its absence. This is an interesting topic that has been intensively debated by contemporary specialists in maritime law and international law, including Christian Buerger (2014), Geoffrey Till (2012), and James Kraska (2013). There is a consensus that maritime security is very difficult to define, with some even suggesting that it may be a buzzword, a multidimensional concept with the capacity to embrace a multitude of possible meanings with different normative resonances (Cornwall 2007: 472). In view of this difficulty, I will try to define this term, based on a proposed typology, as a complex concept which is both convergent and divergent, as stated by Buerger (2015: 160), 'Maritime security can hence be understood in the way it organises older established and more recent concepts.' 
Initially, maritime security may be viewed as a complex concept because it tends to be approached on different levels. Some approaches aim to be universalising, as in the case of UN resolutions (for example, about the coast of Somalia and, more recently, the Mediterranean and the Gulf of Guinea), the International Maritime Organization (IMO) Convention for the Suppression of Unlawful Acts against the Safety of Maritime Navigation (SUA - 1988/2005), or even the IMO Maritime Security Committee (MSC), which added maritime security efforts to its task list. In addition, there have been regional approaches, or specific multilateral arrangements. For example, in 2011, the North Atlantic Treaty Organization (NATO) added maritime security to its list of main objectives through its Alliance Maritime Strategy. The African Union (AU) and the European Union (EU) did the same in 2014. There have been various state-based approaches, such as the pioneering US National Maritime Security Policy launched in 2004, as well as the UK Maritime Security Strategy of 2014. Finally, there are lower-level approaches, some at the intra-state institutional level, as maritime security is often a concurrent, complementary or shared responsibility of a Navy, Coast Guard, and other national institutions. Therefore, taking into account the diversity of institutional commitments, maritime security can be regarded as a complex issue, due to the difficulty of bringing expectations at various levels together in unison.

The proposed typology mentions that in addition to being complex, the concept of Maritime security is also both convergent and divergent. It is convergent because it involves terminology with multiple meanings which can therefore accommodate distinct epistemic nuances - and also because topics traditionally considered in the context of safety can also affect security. The overlap between issues that allow complementary approaches to safety as well as security has grown. This conceptual broadening that has enabled several themes to converge on the concept of maritime security may be related to similar trends in respect of other concepts such as human security, and even peace-building (Gasper 2005). Converging on something of general interest may facilitate agreements based on similar interests among stakeholders.

Finally, the proposed typology of maritime security can be seen as divergent. This term is used to show that, while at its core maritime security involves actions at sea that affect all regular navigation, it also involves other issues. Christian Buerger (2015) has proposed four quadrants around maritime security: national security, human security, the environment, and the economical use of the seas. These four quadrants contain subtopics, some closer to the core and others more peripheral, reflecting interests that may be national or international, short-term or ongoing.

Most analysts agree that maritime security encompasses some issues related to interstate conflict such as piracy (or armed robbery, when the incidents occur in state territorial waters) and terrorist acts. Trafficking in weapons of mass destruction, drug trafficking, smuggling, and human trafficking have also been added. It is also no longer possible to discuss maritime security while ignoring newer topics such as the exploitation of living resources (fishing and bioprospecting), the exploitation of the sea bed, ocean pollution, and natural and human-caused accidents with serious consequences, including climate 
change. While further from the core, all these issues need to be considered. Each is mainly related to a single quadrant, but many also affect several of them. This is why I propose to consider maritime security as a complex, convergent and divergent concept.

In order to discuss the possibilities of multilateral action for ensuring peace and maritime security, this concept must therefore be delimited further. Fighting against exploitative bioprospecting is quite distinct from fighting against the trafficking of drugs, or the smuggling of contraband. On the other hand, based on the proposed complex typology, some maritime threats are more localised, and have more limited repercussions than others. For example, illegal fishing in a particular area usually affects only the economy adjacent to it, making this a problem for the coastal state whose law is being flouted. Other threats may have a wider but still limited impact. For example, arms trafficking in the Lebanese coastal region directly affects the Middle East, but also has global consequences, which can lead to responses from actors outside the region such as the Maritime Task Force (MTF) of the UN Interim Force in Lebanon (UNIFIL) (UN 2010).

Some threats have become global, and therefore ask for international intervention. Some actions have been undertaken, and certain maritime areas are regarded as particularly worrying in terms of maritime security. Piracy off the east coast of Africa, initially around Somalia, has provoked a significant international response. More recently, the west coast of Africa, known as the Gulf of Guinea, has also attracted more attention, mostly due to cases of armed robbery, but also of piracy. ${ }^{1}$ Another prominent problem arising from the lack of maritime security - but with a different cause - is that of migration flows and human trafficking in Mediterranean waters.

Given this typology and the related examples, it is possible to demonstrate that there are multiple and distinct alternatives for dealing with each of these threats. Some involve major international engagements (by multilateral and international organisations), and others more national responses. Given this, I am limiting this analysis only to UN initiatives (the most comprehensive level in the complex typology) as a means of dealing with a lack of maritime security.

\section{The UN role in maintaining world peace and security}

While the $20^{\text {th }}$ century was not the most confrontational in history, it witnessed the outbreak of wars transcending borders, impacting on areas around the globe. The worldwide reach of hostilities led to two conflicts called World Wars for the first time. Following World War I, the global desire for peace inspired the founding of the League of Nations (LN) in 1919. The age-old desire to regulate the use of force by states was finally attempted. However, the proposed organisational structure was unable to withstand the stresses encountered in subsequent decades (Garcia 2005).

While this first modern experiment in creating a universal organisation of states dedicated to international peace and security did not prosper, it nevertheless established certain precedents in the field of multilateral co-operation for solving conflicts. While not 
formally defined as such, Peacekeeping Operations (PKOs) are now seen as dating back to that period (Garcia 2005).

The shortcomings of the LN became apparent with the outbreak of World War II. It was clear that the LN could not muster or guarantee the resources needed to preserve peace. Thus, the great powers began to consider the establishment of a new international organisation. Negotiations began during the war, culminating in the Dumbarton Oaks Conference - held while the conflict was still raging, from August to October 1944 where China, the USA, the UK and the Soviet Union met to discuss the matter and formulate the Charter of a future United Nations. On 26 June 1945 (UN 1945), the Charter of San Francisco officially established this international organisation as a new intergovernmental instrument for ensuring international peace and security.

While the term 'collective security' does not appear in the UN Charter, its agreed use began to emerge in UN documents. For example, Resolution 377 (V) of the UN General Assembly (UNGA) dated 3 November 1950 stated that the body was

[...] fully conscious that, in adopting the proposals set forth above, enduring peace will not be secured solely by collective security arrangements against breaches of international peace and acts of aggression, [...] Urges Member States to intensify joint action, in cooperation with the United Nations (UN Res A/377(V), 1950: 48-9).

This demonstrates the international concern with delimiting inter- and intra-state relations capable of achieving the utopian goal of universal peace. This was no longer a matter of initiatives or actions by individual states, but rather of shared responsibilities for guaranteeing peace.

As regards the regulatory dimension, Section 1, Article 1 of the UN Charter states:

To maintain international peace and security, and to that end: to take effective collective measures for the prevention and removal of threats to the peace, and for the suppression of acts of aggression or other breaches of the peace, and to bring about by peaceful means, and in conformity with the principles of justice and international law, adjustment or settlement of international disputes or situations which might lead to a breach of the peace.

In the context of the UN claim to universality, this placed no territorial restrictions on where it could act to maintain 'international peace and security', notably the territory of member states only. I will use this as a further argument in favour of maritime PKOs. It could be argued that the reference to 'conformity with the principles of international justice and law' obviates the need to explicitly state that the UN could act only in the territories of member sates, as pacta sunt servanda - i.e., 'states are bound only by the agreements into which they have entered' - is a prominent principle of international law (Mello 2004).

However, this objection falls apart in the face of the UN's claim to universality, now covering almost the entire terrestrial globe (193 member states). Moreover, the three UN 
conferences on the Law of the Sea (in 1958, 1960 and 1973-1982) have expanded its mandate to regulating maritime spaces. This effort culminated in the UN Convention on the Law of the Sea (UNCLOS) of 1982, which has also gained near-universal status, as 168 states had fully acceded to it by June 2016 (UN 2016).

This shows that the UN created various instruments for 'maintaining international peace and security'. During the Cold War, the great powers often used their UN Security Council (UNSC) vetoes to paralyse efforts to resolve various conflicts. The UN often tried to address these crises by using non-coercive measures provided for in Article 41 of its Charter.

While the Charter enables the UN to establish its own armed forces, practical problems have prevented this from being implemented. While use of the veto would have paralysed decision-making in the UNSC, the failures of the Military Staff Committee precluded any possibility of implementing the collective security mechanism envisaged in the Charter. The non-implementation of the 'special agreements' provided for in Article 43 of the Charter highlighted the need for alternative instruments acceptable to the five permanent UNSC members, in order to allow the UN to operate. The most important of these instruments were PKOs.

Proposals were made for establishing UN Armed Forces or a rapid deployment force, including the proposal for a police force presented by UN Secretary-General Trygve Lie in 1948 (which served as a model for creating the UN Guards who worked in northern Iraq in 1991), and proposals for the rapid deployment of national military forces (set out in the 1951 report of the Collective Measures Commission created by section C of Resolution 377 (V) of the United Nations General Assembly (UNGA) in 1950). But none of these initiatives prospered.

This failure ultimately encouraged the 'establishment of an innovative mechanism: peacekeeping operations' (Cassese 2005: 339) - an ultra legis instrument that has become a settled approach in the UN's life of just more than half a century.

\section{The scope for Peacekeeping Operations}

International society, understood as a set of political actors and subjects of law (Bull 2002), has come to accept the international protection of peace through an international organisation (IO). This is based on the understanding that the function of 'guardian of the peace' should no longer be subject to the ephemeral protection of a state, or a pact of powerful and influential states. However, it took time for this perspective to become well understood and settled. Since the advent of the UN, single states or coalitions led by a single state have made various attempts to establish PKOs. Much of this happened during the Cold War, such as the US action in Grenada, the French interventions in crises in its former colonies in Africa in the 1960s and 1970s, and the British interventions in Ireland in the late 1960s (Fontoura 1999). This broadening of the notion of 'peace operations' is also visible in post-Cold War actions such as the Russian intervention in Chechnya, and the Australian intervention in East Timor (endorsed by the UNSC, but with the clear inten- 
tion of subordinating one side of the conflict to Australia's pro-independence aspirations), both at the end of the 1990s, and the US-led coalition in Iraq in 2003 (Beirão 2013).

It is questionable whether these interventions were authentic 'peacekeeping operations', as they displayed many characteristics that differed from the principles defined by the UN, such as impartiality (UN 2008: 23-45). Indeed, these actions were not only unilateral, but also lacked the impartiality and neutrality intrinsic to the pursuit of international peace. The principles governing authentic PKOs are clearly set out in the first UN guide to peacekeeping operations, the United Nations Peacekeeping Operations: Principles and Guidelines ('Capstone Doctrine'). Published in 2008, it reflects years of experience and many preceding documents (including Uniting for Peace, 1950; An Agenda for Peace, 1992; Supplement to An Agenda for Peace, 1995; and the Brahimi Report, 2000).

This document defines a fundamental characteristic of PKOs, namely their multilateral character; that is, it presupposes a diversity of power and diffused interests pursuing a single objective, namely peacekeeping. This is confirmed by the collective decision-making process for establishing a PKO. As a general rule, PKOs are established by decisions of the UNSC.

While UN PKOs during the Cold War was limited to maintaining ceasefires and the status quo, these efforts were confined to nations that were on the same ideological side of the Cold War divide. PKOs in that period could be classified as 'classical PKOs', established to manage conflicts and create conditions for inter-state negotiations, as advocated by Paulo Tarrisse da Fontoura (1999: 33-7). This approach was subsequently ratified by the Capstone Doctrine.

During this period, classical PKOs usually faced the difficulty of covert superpower support for the opposing parties, which made it difficult to reduce tensions in conflicts. As a result, several of these PKOs remained active for decades, until political solutions were worked out between the parties (UN 2008: 21). Intra-state conflicts increased after the Cold War. Since 1990, fewer than 10\% of the more than 60 PKOs authorised by the UNSC can be clearly identified as inter-state (Gray 2011: 251).

Growing expectations of the UN in the 1980s developed into a crisis of credibility in the 1990s. Initial enthusiasm over the end of the Cold War bolstered the role of the UN, and it was severely affected by the consequences of broadening the scope and intensity of PKOs. High-level UN summits stated clearly that the organisation would play a more active role, and should be able to respond more effectively to new demands. PKOs occupied a central role in proposals for reformulating the UN's plan of action. However, as James has noted, 'The performance of many PKOs, which was seen as unsatisfactory, exposed the UN's weaknesses, preventing it from emerging as a rejuvenated, key player of International Relations in the 1990s' (James 1990: 33-34).

Fresh changes were required, and the UN itself encouraged studies and suggested new directions. In 2000, Lakhadar Brahimi - then the Algerian minister of foreign affairs - co-ordinated a study group on what the UN needed to do to increase the efficiency and effectiveness of its PKOs (UN 2000). In contrast to the 1992 Agenda for Peace, which was a general document about the effective establishment of PKOs, the Brahimi Report (as it became known) made detailed recommendations for improving UN peacekeeping opera- 
tions. Among other things, it noted that 'simply increasing the number of Blue Berets' or formulating more robust mandates would not improve the PKOs.

Although accurate in many of its diagnoses and prognoses, the Brahimi Report saw scant potential for regional organisations contributing to PKOs. However, since then, this type of PKO has become more prominent. As MacQueen has noted:

At the beginning of the twenty-first century, there are strong forces at the centre pushing peacekeeping out for local attention. Simultaneously, there are peripheral forces tending to pull peacekeeping provision away from direct UN responsibility. The spiralling costs of peacekeeping and the increasing difficulty in enlisting sufficient contributing States makes the regionalization of peacekeeping no less attractive to the UN in the mid-2000s than it was in the mid1990s (2006: 244-5).

This trend has been reinforced by others, notably the development of a fifth generation of PKOs, called Hybrid Operations, in which the UN reinforces and ratifies actions led by regional organisations. (The Capstone Doctrine defined Hybrid Operations as those carried out by more than one international organisation, based on Chapter VIII of the UN Charter.)

Critical thinking about the Brahimi Report may not have gained enough historical distance to state that it was inaccurate in this regard. What is certain is that the UN is facing growing demands for PKOs. However, it has sought to encourage Hybrid Operations, sharing responsibilities with other international organisations or mainly with regional organisations which - due to their better understanding of the conflicts 'on the ground', as well as their own interests - have shown themselves to be highly engaged. A good example of this option is the United Nations Stabilization Mission in Haiti (MINUSTAH), approved by the UNSC in 2004, and jointly co-ordinated by the UN and the Organization of American States (OAS). ${ }^{2}$ That means, under UN Security Council mandate, there is an authorization for others international organisations to act. A more recent example is NATO's action in Libya in 2011, which included air and naval operations.

In this section, I have used a deductive-analytical method to demonstrate that peacekeeping operations are not static instruments, applicable to one type of situation only. While, at the outset, and without doctrinal consolidation, they were only classical interstate operations, they have developed into more multidimensional and hybrid approaches, which opens the door to further doctrinal innovations.

\section{The scope for PKOs at sea}

As noted previously, the UN has assumed the role of regulating the sea. It has been the driving force behind the UNCLOS, and maintains a permanent structure for dealing with maritime spaces, namely the Division on the Law of the Sea (DOALOS).

The preamble to UNCLOS states: 
Believing that the codification and progressive development of the law of the sea achieved in this Convention will contribute to the strengthening of peace, security, cooperation and friendly relations among all nations in conformity with the principles of justice and equal rights and will promote the economic and social advancement of all peoples of the world, in accordance with the Purposes and Principles of the United Nations as set forth in the Charter [...] (UN 1982).

Thus the Convention clearly spells out its intended role of preserving the sea a a peaceful and secure area. While fully acknowledging state sovereignty at sea, this is treated differently from sovereignty on land. Even where coastal states have full sovereignty, such as in their territorial waters, the Convention provides for the entry and exit of vessels without formal state approval, as in the case of 'innocent passage' (Art. 17 and following). This sovereignty decreases as one moves further away from land until one reaches the high sea, which falls outside Exclusive Economic Zones (a maximum of 200 nautical miles). ${ }^{3}$

The UN has been continuously acting as guardian of both the regulation of the maritime spaces falling under States' sovereignty, as well as the maritime zones which lie beyond that region. An example of this territorial extension of UN management is Resolution 2749 (XXV) of the UN General Assembly, which establishes the concept of the seabed and the subsoil of the area beyond the possible jurisdiction of coastal states as the 'common heritage of mankind'. In addition, Article 93 of UNCLOS states:

Ships flying the flag of the United Nations, its specialised agencies and the International Atomic Energy Agency: The preceding articles do not prejudice the question of ships employed on the official service of the United Nations, its specialised agencies or the International Atomic Energy Agency, flying the flag of the organisation.

This shows that, despite unsuccessful attempts to establish UN Armed Forces almost 40 years previously, UNCLOS provided for the possibility of ships flying the UN flag.

This article extends the privileges and immunities accorded to agents in the service of the UN to the maritime dimension. These rights are visible in respect of the Blue Berets, who, while retaining their nationality (and thus their obligations to their home states) enjoy special protection when acting under a UN mandate. In these cases, the UN usually concludes Status of Force Agreements (SOFAs) with those states in whose territories the Blue Berets are operating.

Despite all this, a UN Standing Naval Force will only be established when there is sufficient political will, sufficient training and infrastructure, and adequate funding to support such a multinational force. At the present time, there seems to be no prospect of such a force being established. Perhaps there are real historical reasons why UN member states have not rallied around co-operative efforts on the oceans of the world to the same extent as they have on land (Pugh 1992: 23-4). 
Utilising the rights provided by its Charter, the UN authorises the assembly of multilateral military forces under the aegis of other international organisations to maintain international peace and security. As noted previously, the UN Security Council authorised the NATO military intervention in Libya in 2011, which included classical naval operations in support of air operations. However, the region that offers the most relevant examples is the coast of Somalia. From 2005 onwards, the exponential increase of piracy and hijacking of ships on the East African coast began to threaten international trade as well as lives. This led to various naval operations in the area, several of which were authorised by the UN, including the multilateral EU Naval Force (EUNAVFOR), NATO's Naval Force, other multilateral initiatives, and individual Chinese, Indian, Russian, and even Japanese vessels.

Therefore, it can be said that, although the UN has not worked directly with ships under its own flag and mandate, it has effectively been 'outsourcing' its legitimate function to undertake peacekeeping actions at sea. As Ghebali has noted, 'The main thrust of the argument is that, in certain circumstances, the international community's choice lies between abdication or outsourcing, all the more since some conflicts can only be resolved by enforcement measures' (Ghebali 2006: 224-6).

While the examples referred to above differ in terms of their mandates and the actions undertaken, they all involve action in a theatre of naval operations. In other words, whether conducting joint actions or authorising other organisations, arrangements or national initiatives to conduct actions, all these initiatives display elements of an international custom - a general practice accepted as law (Article 38(1)(b) of the Statute of the International Court of Justice, UN: 1945). It should be noted that these actions did not occur in Somali territorial waters; on the contrary, they occurred in waters with a lesser or no degree of coastal state sovereignty, until 2010, when they reached 400 nautical miles off the African coast (IMB 2014).

At the same time, mandating naval forces under the aegis of the UN to perform maritime actions is not entirely novel. For example, in January 1992, the UNSC mandated the UN Advance Mission in Cambodia (UNAMIC) to train Cambodians in marine minedetecting operations. This was not a military action arising from the needs of a land action, but a specifically naval action, requiring specific methods and training. After the 2010 earthquake in Haiti, MINUSTAH also carried out maritime patrols and surveillance around the coastal capital of Port-au-Prince. In this instance, the naval operation clearly developed out of the operation on land. Therefore, while neither of these examples constitute eminently maritime peacekeeping operations, they do provide precedents for a broadening of doctrine.

Maritime PKOS have received increasing attention from scholars, notably Michael Pugh $(1992,1994)$ and Rob McLaughlin. McLaughlin's book United Nations Peace Operations in the Territorial Sea (2009) only dealt with naval operations in territorial waters, but aids an understanding of direct UN action in areas which third states may enter, such as the right of innocent passage through territorial waters. Meanwhile, these initial studies have highlighted concepts and principles that have reinforced the legitimacy of the UN leading naval operations. 
While the complex issue of how best to organise peacekeeping operations falls outside the scope of this article, it does affect future UN operations at sea. In Multinational Peacekeeping in the Middle East, Robert Houghton and Frank Trinka (1985) suggested four prerequisites for establishing a successful peacekeeping operation, and Robert S Staley had attempted to adapt these principles to potential multinational maritime operations (Staley 1992: 20).

More recently, one of the most durable active PKOs - the UN Interim Force in Lebanon (UNIFIL) - identified the need to establish a Maritime Task Force (MTF). On 11 August 2006, UNSC Resolution 1701 duly authorised the PKO to operate at sea. Since then, states contributing to the operation have sent larger naval units (frigates and corvettes, among others) for actions along the Lebanese coast. Since 2011, the MTF has been commanded by an Admiral of the Brazilian Navy, working from a Brazilian flagship vessel. While this naval force was originally established to operate in Lebanese territorial waters, the local operational headquarters identified a need to expand maritime patrol and surveillance beyond the 12-mile limit of the Territorial Sea, extending it up to 50 miles, and this has been ratified by the UN. In addition, the establishment of a multilateral force made up of units from more than 15 different navies has been used to develop the doctrinal foundations for engagement, UN support, and the rules to be observed (UN 2016).

One possible objection to the deployment of maritime PKOs established by the UN and using a UN doctrinal and institutional framework may arise from a restrictive interpretation of the UN as an international organisation made up of member states. The UN Charter stipulates that it may only conduct actions on the sovereign territories of member states, which excludes the high sea.

However, the UN has conducted operations in Kosovo without considering whether or not the locus of the operation was in a non-member State. (It could be argued that, prior to the conflict, the region belonged to the former Yugoslavia, which was indeed a UN member). The UN conducted lengthy operations in Palestine before it was granted non-member observer status in 2012. There are also more clearly defined cases of UN operations in regions with no internationally accepted sovereignty, such as Antarctica. Moreover, the UN has led UNCLOS, the largest global initiative yet to settle the laws and customs of the sea. These actions confirm the theory of implied powers developed by Grigory Tunkin, former Ministry of Foreign Affairs of the USSR, in a statement to the International Court of Justice (ICJ 1950: 97).

In light of the above, it seems clear that international society has indeed legitimised the UN's role of protecting the seas, either via direct action or indirectly, via multilateral arrangements. Other researchers have also argued in favour of increased UN activity at sea. Thus McLaughlin has noted:

Furthermore, as a high water mark, UN transitional administration holds significant, almost quasi-sovereign, implications for authority in UN naval peace operations, and as with the interdiction operations discussed, hints at implications for UN naval peace operations in third state Territorial Seas (2009: 172). 
And Parkhouse has argued,

The evolution of a comparable United Nations unified naval command must be driven by the very real and unpredictable threats to global maritime peace and prosperity. Given the bleak outlook for the security climate of the future, the efficacy of a United Nations Standing Naval Force will be irrefutable (1997: 78).

Based on the above analysis, the following factors can be cited in favour of establishing maritime PKOs in this new context:

- The primary goal of the UN is to maintain international peace and security, anywhere on the globe.

- International demands have mounted for action to mitigate risks to maritime security, and threats to maritime security are increasingly seen as threats to international security. These include concerns over the rapid incrase in maritime migration in the Mediterranean Sea, as well as the attacks in the Gulf of Guinea, which have put commercial shipping at risk. The threats to human life and safety in the Mediterranean involving vessels full of refugees, as well the risk to commercial traffic, constitute clear challenges to 'international peace and security' as defined by Article 1 of the UN Charter. These concerns are reflected in the growing number of UNSC resolutions calling for actions to be conducted and positions to be taken in these two areas. ${ }^{4}$

- UNCLOS, which is almost universal, provides for direct UN action at sea, and supports the universal goal of preserving the peaceful use of the sea.

- The operational instrument most used by the UN to mitigate threats to international peace and security is that of PKOs, especially in the post-Cold War period.

Why not take advantage of the lessons learnt from these successful innovations and establish maritime PKOs? What is proposed here is a $\mathrm{PKO}$, under UN mandate, authorised by the UNSC, with the full support of its Department of Peacekeeping Operations (DPKO), rather than 'outsourcing' this function to other multilateral bodies or arrangements. Innovating is difficult, but the role of inductive logic is precisely to devise new solutions for existing problems, and adapting them to become solutions for new problems as well'. A large body of doctrine would need to be developed, but, as the Brahimi Report highlighted, the UN should continue to evolve in order to help the new century take shape.

Many documents which are fundamental to the establishment of a PKO - including the Status of Force Agreement (SOFA), the Memorandum of Understanding (MOU), the Status of Military Agreement (SOMA), and the Rules of Engagement (ROE) - presuppose the sign-off of formal acceptance of the PKO by the hosting party. However, the Brahimi Report noted that some situations require urgent action, and that it is not always possible to wait for the international formalisation of hosting states and contributor states. In the past, the UN itself has sought solutions when sign-off has been slowed down, when the action constitutes a 'Peace Enforcement,' or when it is unable to make a minimal determination about the legitimacy of the officers meant to sign the agreements. 
For example, in order to ensure the immunity of its Blue Berets, the UN has adopted a Standard SOFA developed by the research group at the Law School of the University of Essex (ESSEX 2011). This is a generic and pre-prepared document that remains infoce until such time as another agreement can be reached.

This amounts to a unilateral act on the part of the UN (with the implied support of the international community), applicable in the hosting territory, prior to the formal agreements on the actors and procedures. The maturity of UN procedures for conducting PKOs also serves to legitimise its efforts to address new conflict situations, so that this quasi-unilateral action has been reinforced by the DPKO and recognised by the General Assembly (Res A/45/594, 1990).

A possible argument against the establishment of maritime PKOs is the difficulties of providing logistical support, and the need for naval forces operating offshore to have a high level of endurance. ${ }^{5}$ However, there are numerous examples of successful arrangements for providing logistical support. To give one example, if a maritime PKO were set up in the Mediterranean, the UN could sign agreements with member states close to the theatre of operations - even though they may not be contributor states to the PKO - to use their naval bases for refueling and maintenance of the UN forces. This could also be done in other areas. There are always naval bases relatively close to maritime operations that would allow logistical support.

There is a need to develop doctrine along these lines at several levels, from the political sphere - which is most affected by UNSC decisions and legitimisation by the international community - to the operational and tactical levels. However, there are clear signs of progress being made on many of these levels. For example, in September 2015, the UN itself, under the supervision of the Department of Peacekeeping Operations (DPKO) and the Department of Field Support (DFS), prepared and published the United Nations Peacekeeping Missions - Military Maritime Task Force Manual. This document, in addition to other UN doctrinal documents, has been very useful for consolidating procedures, although mainly at the operational and tactical levels.

The manual is primarily about the operational and tactical levels. It is based on UN guides reflecting lessons learned, feedback from field missions, and input from participants in UN Maritime Task Force peacekeeping operations. Workshops conducted by interested member states and troop/maritime contributing countries produced a first draft which was finalised after extensive co-ordination and conslution within the DPKO and DFS. The result is a comprehensive body of thought about UN Maritime Task Forces designed to assist contingents in reorienting their Maritime Task Force elements towards interoperability in UN peacekeeping.

This manual should be read in conjunction with relevant UN policies and other manuals, especially the UN Infantry Battalion Manual, in order to gain a more comprehensive understanding of UN standards, policies and procedures related to peacekeeping operations. Moreover, the Capstone Doctrine provides more in-depth information about the Mission concept (UN 2015: 5).

Given the nearly universal character of UNCLOS, and the gradual recognition of actions at sea under the command of the UN, it can be accepted that most or all UN mem- 
bers would accept and respect maritime operations undertaken under the UN flag. Good order at sea would be emphasised rather than the freedom of navigation principle, and would be useful for the peaceful use of the sea.

\section{Final considerations}

This article has examined the feasibility of establishing maritime PKOs, led by the UN and employing prioritised Naval Forces, as another solution to improve maritime security, and maintain good order at sea. It has shown that much would need to be done to achieve doctrinal maturity and the international recognition of PKOs of this nature.

However, despite the fact that the UN Charter does not provide for PKOs, they have become an accepted instrument for intervening in interstate conflicts. Given the political and security dynamics of the of the post-Cold War era, most peacekeeping operations at sea have responded to intra-state conflicts.

The development of doctrines along these lines has resulted from the need to improve the founding documents for PKOs, with increasingly robust mandates, using standard documents in cases where negotiations over the formal agreements drag on for too long, which could impact on the timely performance of actions. It demonstrates that the international community has recognised the legitimacy of the UN to act in this way.

It also shows that the maintenance of peace at sea has evolved. While previous concerns involved traditional inter-state conflicts, in an increasing number of cases, the reasons for the lack of security have not been based on the classical conflict between naval forces. New threats such as human trafficking and migration without regard for minimum safety conditions, as well as piracy, armed robbery, and trafficking in arms and drugs have emerged as serious threats requiring international responses. However, many actions have been based on isolated state initiatives, multilateral arrangements or other international organisations, which have been signed off by the UN, without any direct action.

Therefore, it may be timely for the UN to resume the creative thinking that resulted in establishing PKOs as its primary instrument for maintaining international peace and security, and introducing eminently maritime PKOs. As stated at the beginning, past experiences allow the development of new concepts, while also - provided that they are based on an adequate legal and scientific framework - allowing extrapolations.

This article has sought to rethink some of the main concerns of the new threats to maritime security in the $21^{\text {st }}$ century, in order to help find solutions that could satisfy the universal desire for the peaceful use of the sea. While the sea occupies more than $70 \%$ of the earth's surface, it is the most recent area to receive universal regulation. Perhaps for this very reason, it will also turn out to be the setting that gives rise to the most annotative approaches to the pursuit of increased maritime security.

\section{Notes}

1 According to UNCLOS, piracy occurs in waters that are not within the jurisdiction of any state, which essentially means areas beyond countries' Exclusive Economic Zones (Article 101). Armed robbery 
involves actions that, while employing the same means, are practiced in territorial seas. However, this distinction is sometimes disputed. While the repressive actions may be the same, this distinction may give rise to actions conducted with varying degrees of regulatory rigor and international support. This may be one of the reasons why the 'resurgence of piracy' has sparked so much debate.

2 The UNSC is mandated to authorize Peace Missions, which are then established and managed by the Department of Peacekeeping Operations (DPKO) in line with the Capstone Doctrine of 2008.

3 Sovereignty at sea is a complex issue that requires an understanding of various zones at increasing distances from the coast, as established by UNCLOS. See Beirão 2015.

4 Gulf of Guinea: S/RES/2039 of February 29, 2012 and S/RES/2125 of November 18, 2013. Mediterranean: S/RES/2312 of October 6, 2016 and S/RES/2240, of October 9, 2016.

5 Naval Forces traditionally have three fundamental characteristics, namely flexibility, mobility and endurance. Flexibility refers to the capacity of marine resources and their crews to adapt to new types of missions. Mobility refers to their ability to move to new areas and conduct actions there, and endurance to their capacity to be practically autonomous, relying on their own resources and requiring logistical support less frequently than land and air forces, thus giving them more time for permanent action in the theatre of operations.

\section{References}

Beirão, André Panno. 2013. In Bello, Pax: a responsabilidade penal dos brasileiros em Operações de Paz. PhD Thesis. University of the State of Rio de Janeiro (UERJ), Rio de Janeiro.

. 2014. 'Segurança no mar: que segurança?'. In André Panno Beirão and Antônio Celso Alves Pereira (eds), Reflexões sobre a Convenção do Direito do Mar. Brasília: FUNAG, pp. 127-66.

. 2015. 'Duelo entre Netuno e Leviatã: a evolução da soberania sobre os mares'. Revista da Escola de Guerra Naval, 21 (2): 63-91.

Blackham, Jeremy J. 1993. 'Maritime peacekeeping. The RUSI Journal, 138 (4): 18-23.

Buerger, Christian. 2015. 'What is maritime security?' Marine Policy, 53: 159-64.

Bull, Hedley. 2002. The Anarchical Society. New York: Columbia University Press.

Cassese, Antonio. 2005. International Law. $2^{\text {nd }}$ Edition. New York: Oxford University Press.

Cornwall, Andrea. 2007. 'Buzzwords and fuzzwords: deconstructing development discourse'. Development in Practice, 17 (4): 471-84.

Fontoura, Paulo Roberto Campos Tarrisse. 1999. O Brasil e as Operações de Manutenção da Paz das Nações Unidas. Brasília: FUNAG.

Garcia, Eugênio Vargas. 2005. O Brasil e a Liga das Nações (1919-1926): vencer ou não perder. $2^{\text {nd }}$ ed. Porto Alegre: UFRGS.

Gasper, Des. 2005. 'Securing humanity: situating "human security" as concept and discourse'. Journal of Human Development, 6 (2): 221-45.

Ghebali, Victor-Yves. 2006. 'The United Nations and the dilemma of outsourcing peacekeeping operations'. In Alan Bryden and Marina Caparini (eds), Private Actors and Security Governance. Berlin: LIT Verlag Münster, pp. 213-28.

Gray, Collin S. 2012. War, Peace and International Relations: An Introduction to Strategic History. $2^{\text {nd }}$ ed. New York: Routledge.

Houghton, Robert B and Frank G Trinka. 1985. Multinational Peacekeeping in the Middle East. Washington, D.C.: US Foreign Service Institute, Dept. of State. 
International Maritime Bureau (ICC). 2014. Piracy and Armed Robbery Against Ships: Report for the Period 1 January- 31 December 2014. At http://www.hellenicshippingnews.com/wp-content/ uploads/2015/01/2014-Annual-IMB-Piracy-Report-ABRIDGED.pdf. [Accessed on 10 May 2016].

James, Alan. 1990. The Politics of Peacekeeping. London: MacMillian and International Institute for Strategic Studies.

Kenkel, Kai Michael. 2013. 'Five generations of peace operations: from the "thin blue line" to "painting a country blue”. Revista Brasileira de Politica Internacional, 56 (1): 37-52.

McLaughlin, Rob. 2009. United Nations Naval Peace Operations in the Territorial Sea. Leiden: Martinus Nijhoff.

Mello, Celso Duvivier de Albuquerque. 2004. Curso de Direito Internacional Público. $15^{\text {th }}$ ed. Rio de Janeiro: Renovar.

Parkhouse, Owen J W. 1997. Naval Diplomacy and the United Nations: Naval Peacekeeping in a New World Order. MA Thesis. Dalhousie University, Halifax.

Pugh, Michael. 1992. 'Peacekeeping - A Role For Navies?' Paper delivered at Naval Forces: International Forum for Maritime Power. Road Island, USA, 15-27 August.

1994. Maritime Security and Peacekeeping: A Framework for United Nations Operations. New York: Manchester University Press.

Redman, Peter. 2006. Good Essay Writing: A Social Sciences Guide. $3^{\text {rd }}$ ed. London: Open University. Staley, Robert Stephen. 1992. 'The wave of the future: the United Nations and Naval Peacekeeping'. International Peace Academy Occasional Paper Series. UK: Lynne Rienner.

Tunkin. Gregory. 2009. Corte Internacional De Justiça. Relatórios. 1950. In Aziz Tuffi Saliba, Conselho de Segurança da ONU: sanções e limites jurídicos. $22^{\text {nd }}$ ed. Curitiba: Juruá.

United Nations (UN). 1970. General Assembly Resolution Nr 2.749, 17 December. (XXV General Assembly)

. 1982. United Nations Convention on the Law of the Sea. At http://www.un.org/depts/los/ convention_agreements/texts/unclos/unclos_e.pdf [Accessed on 10 March 2016]

. 1992. Security Council Resolution Nr. 728, 8 January. Enlargement of the mandate of UNAMIC.

. 2006. Security Council Resolution Nr. 1.701, 11 August. United Nations Interim Force in Lebanon.

. 2016. United Nations FTM -UNAFIL Operational Map. At http://www.wikiwand.com/de/ United_Nations_Interim_Force_in_Lebanon . [Accessed on 12 April 2016]__ . 2015. United Nations Peacekeeping Missions - Military Maritime Task Force Manual. At http://www.mpsotc.gr/ dat/5CA88879/file.pdf. [Accessed on 03 April 2016]

University Of Essex, School of Law. 2011. 'UN Peacekeeping and the Model Status of Force Agreement'. At https://www.essex.ac.uk/plrp/documents/model_sofa_experts'_workshop_march_2011. pdf. [Acessed on 12 February 2013].

\section{Acknowledgements}

The author would like to thank the Brazilian Ministries of Education (CAPES/MEC) and Defence for their support of the research programme "PRODEFESA III". The concepts and thoughts pre- 
sented in this article express the author's own ideas and do not represent any official thinking or positions held by the institutions he is affiliated to.

\section{About the author}

André Panno Beirão holds a $\mathrm{PhD}$ in International Law from the State University of Rio de Janeiro (UERJ), an MA in Political Sciences from the Federal University of Rio de Janeiro (UFRJ), and an MA in Naval Sciences from the Brazilian Naval War College (BNWC), Brazil. He is Brazilian Navy Capitan (Rtd), and Senior Researcher at the Brazilian Navy Political and Strategic Studies Centre and Pro-Defesa III (Brazil and Atlantic South Security). He won the Prize of the Brazilian Ministry of Defence for the best PhD thesis about National Defence in 2012-2014. He is currently Deputy Coordinator of Brazilian Political Sciences and International Relations Professional Postgraduate Programmes at the Coordination for the Improvement of Higher Education Personnel (CAPES) in the Brazilian Ministry of Education.

Received on 18 July 2016, and approved for publication on 20 February 2017.

\section{(cc) BY-NC} https://creativecommons.org/licenses/by-nc/4.0/ 